\title{
NEW QUALITY OF FINANCIAL INSTITUTIONS AND BUSINESS MANAGEMENT
}

\author{
Nataliia Kraus ${ }^{1}$, Kateryna Kraus ${ }^{2}$, Valerii Osetskyi ${ }^{3}$
}

\begin{abstract}
Economic processes in the world are characterized by a high level of dynamism, change and innovative approaches to addressing key issues in nowadays. In a context of globalization and European integration of Ukraine into a high-tech competitive environment in order to financing innovative projects, it is necessary to use Blockchain technology as an effective tool for digital economy. Purpose of scientific research is to find out key priorities and functionalities of Blockchain's application for solving business and government tasks. The object of scientific research is the latest financial technology Blockchain and a system of cult-technologies: crowdsourcing, crowdfunding, crowdinvesting. Methodology. In the process of research, the following methods are used: generalization is used in studying the nature, preconditions and principles of Blockchain technologies; formalization is used when comparing characteristics of the latest forms of financing, such as crowdsourcing, crowdfunding, crowdinvesting. In the course of scientific research, key qualitative characteristics of digital economy are described and the dominant components of its development are investigated. The result of the article. The priorities, new principles of business management and possibilities of Blockchain technology as an effective digital economy tool for solving business and government tasks are revealed. Future prospects from the implementation of crowd-technologies as an effective management tool in progress for solving the problems of innovative business are substantiated. Interconnection in the latest financial institution of creative initiatives realization is presented. The comparative analysis of management of new institutes of innovative development for Ukrainian economy in the course of doing business is carried out. The result of the research is presentation of the relationship in the latest financial institution implementing creative initiatives and a comparative analysis of new institutes of innovative development in the sphere of finance for the Ukrainian economy. Practical implications. The components of digital economy identified by the authors in the article are accelerators of the socio-economic life of Ukrainian society in the modern world and are capable of rapidly increasing Ukraine's GDP. The described new forms of financing of Ukrainian startups (crowdsourcing, crowdfunding, crowdinvesting) are today quite interesting and effective tool for solving business problems in the financial, economic, innovative and marketing spheres. Value/originality. Blockchain technology, as an effective tool for Ukraine's digital economy, is able to address the challenges of business and government, uncover the relationship between crowdsourcing, crowdfunding, crowdinvesting, and explain the content of innovative financial institutions for Ukraine's economy.
\end{abstract}

Key words: innovations, imperative of management, Blockchain technology, crowdfunding, crowdsourcing, crowdinvesting, fintech projects.

JEL Classification: B15, B25, O15, O32

\section{Introduction}

We live in times of enormous transformation. All aspects of the habitual life are radically changing. The world is becoming unrecognizable and needs new approaches to the problems of development and economic growth. Not only new strategies of the state and business are needed, but also a new way of financial thinking of the modern generation and another level of education and science (Palchuk, 2013).

\footnotetext{
Corresponding author:

${ }^{1}$ Borys Grinchenko Kyiv University, Ukraine.

E-mail: k2205n@ukr.net

ORCID: https://orcid.org/0000-0001-8610-3980

ResearcherID: W-1814-2017

${ }^{2}$ Borys Grinchenko Kyiv University, Ukraine.

E-mail:k23k@ukr.net

ORCID: https://orcid.org/0000-0003-4910-8330

ResearcherID: F-3710-2017

${ }^{3}$ Taras Shevchenko National University of Kyiv, Ukraine.

E-mail: val_osetski@ukr.net

ORCID: https://orcid.org/0000-0001-5104-1070
} 
For example, the volume of investments in fintech projects in the world is increasing. Therefore, in 2016, it grew by $11 \%$, compared with 2015 and amounted to 17.4 billion USD. The giants of on-line commerce, retail and other industries have long understood the fact that customers choose leaders with a strong fintech component. Alibaba, Amazon, Auchan, Apple, Samsung have already made their own payment services an important part of their business ecosystems. In Asia, bank card payments are the last stage, people pay for goods and services through installed on the smartphones AliPay or WeChat. In the future, the purpose of the smartphone will be to make payments. They will be paid for the purchase of products in a supermarket, will be billed in cafes, hotels, taxi and other transport.

We are convinced that with the help of the latest financial technologies, cus-tomers can be returned to the center of the financial ecosystem and, at the same time, ensure that banks provide important services that support the foundation of society. The relationship between small and medium-sized businesses and consumers of retail banking services will be a key element in this issue. Whether due to payments or the loyalty system, the client must be sure that the value fintech suggestions are directed, first of all, to it.

The processes of the European integration of Ukraine into a high-tech competitive environment have led to the necessity of forming an innovative model of development and business management, in which role of the main source of long-term economic growth are playing scientific achievements and their technological application and new forms of financing of innovative business projects. Science and innovations are considered not only as a foundation and an instrument for improving competitiveness and financial and economic security, but also as a basic element of a new type of society, based on knowledge, ideas, creative abilities of innovators (Zatonatskaya, 2011).

The purpose of the article is to study the priorities and possibilities of functioning of Blockchain technology as an effective digital economy management tool for solving business and government tasks, disclosing the relationship between crowdsourcing, crowdfunding, crowdinvesting, and an explanation of the content of new innovative enterprises for business economy of Ukraine such as Fintech in the course of doing business.

Information basis of the article are scientific works of Ukrainian and foreign scientists, materials of periodicals and Internet resources. In the research process, the following methods are used: generalization is performed in studying the nature, preconditions and principles of Blockchain technologies; formalization is used when comparing characteristics of the latest forms of financing, such as crowdsourcing, crowdfunding, crowdinvesting.

\section{Literature review}

Scientific thought of modernity is aimed at substantiating the mechanisms of formation and tools of development of a socially oriented state and business economy, which is practically impossible to construct using traditional theories and teachings. However, issues regarding the development and implementation of digital business-economy are insufficiently researched. Modern technological transformations in the direction of the formation of digital economy also transform the institutional basis of behavioural motives of researchers/ innovators, scientists and business entities.

It is noted that in the theory of scientific research the categories of "paradigm" and "imperative" are interdependent. The imperative comes from the Latin "imperativus", i.e. imperious, which is interpreted as a command, a mandatory requirement, an order, a law, an unconditional principle of conduct, bringing to a certain order (Imperative, 2017).

The purpose of the imperative is to determine the dominant scientific direction in the specific historical conditions of the socio-cultural space. Regarding the paradigm, its problems under study researchers interpret as a basic conceptual scheme (example, sample) (Arner, Barberis \& Ross, 2015), a model for setting problems of the formation of digital economy and their solution, methods of research that are ruling, relevant and predominate in science today. We share the opinion of $\mathrm{H}$. Zhavoronkova and V.Zhavoronkova in the question of main characteristics of paradigms (Zhavoronkova, 2015), which they attributed to the following: functionality, prevalence, adaptability, dynamism, multivariate, manageability.

According to the leading Ukrainian scientist O. Zavgorodnia, "the most active and fruitful searches are localized at the mega and micro levels of the course of innovative business processes (Zatonatskaya, 2011). In particular, modern economists consider digital technology as an attribute of a new business economy, regardless of which epithet is using as its criterion" (Cassar, Heath \& Micallef, 2018).

We share the views of L. Antonyuk on the identified barriers to the development of high-tech innovative enterprises, but the scholar highlights the ability of their further prosperity, we call them inexhaustible and those that require significant revision. Considerable attention in contemporary scientific literature is devoted to the development of the model of innovative management of enterprises, to find out the causes of problems of their modernization and the establishment of development priorities and barriers to effective management, as well as the implications of introducing financial innovations into economic activity (Lerner, Tufano, 2011).

\section{Determinants of digital business economy}

Under the ability to be considered a digital business economy, it is necessary to understand the property 
of the economic system, which manifests itself in the ability to generate digital technologies and innovations of all types, in the context of different levels of economic aggregation, while providing exclusively an intensive type of development and business management.

In addition, digital economy bases on the latest technology and all sorts of managerial innovation. We are convinced that due to this economy a new, high quality and special, not known to date, world order that organizes the work of Internet society. Key determinants of digital business economy are:

- Security of documentation through an automatic digital management solution, without the need for clients to contact the branches of the bank;

- Ability to use Blockchain technology, with its advanced services, while pursuing the goal of increasing and facilitating the business process of digitalization. In addition, the change in the data "pre-number" when used Blockchain technology becomes impossible;

- Qualitatively new standard of living and quality of life (nature and conditions of work, education, features of leisure, living conditions, socio-psychological climate at enterprises, etc.);

- New quality of interconnections and management interaction between enterprises, society and the state (the principle of the most complete and timely performance of duties to each other, the possibility of providing new services);

- Emergence of disruptive innovation (as a category used not only to refer a product or process at a certain fixed point, but as a process of their evolution in business for a certain time, characterizing their subversive nature through the path of retreat from the mainstream (Christensen, Raynor \& McDonald, 2015)). Innovative entrepreneurs tend to focus on getting an effective business model, not just a product, with business model based on digital innovations significantly different from traditional ones;

- Saving free time of individuals because of functioning of this economy ("softening" the load on individuals, increasing the level of mechanization and automation of production, systematic and complex modernization and reforming health care management system and the Ukrainian education, etc.).

\section{Blockchain technology}

Digital economy is an accelerator of the socioeconomic life of society in modern world and is capable of rapidly increasing the GDP of the country. Ukraine was the first in the world to launch a state electronic auction based on Blockchain cryptographic technology. Blockchain is a way of storing data or a digital registry of transactions, agreements, contracts. When using digital recordings are combined into blocks, which are then cryptographically bind and chronologically in a chain by using complex mathematical algorithms.
The encryption process is performed by a large number of different computers running on the same network. As soon as the registry is updated and a new block is created, it cannot be changed anymore. Thus, it is impossible to fake it. Any user of this network has free access to the current version of the registry (Today, 2017).

This technology provides for decentralized storage and protection of infor-mation and can lead to the replacement of classical business functions of banks, notaries, even state-owned, to eradicate corruption, to ensure the full transparency of all business processes and to give a huge competitive advantage to the country (Hroisman, 2017). Blockchain is capable of providing transparency, security, speed of operations and data protection. Today, a number of companies and the government of Ukraine are experimenting with technology in the hope of reducing corruption and the ineffectiveness of their business processes (The largest bank..., 2017).

\section{Foreign experience in using Blockchain technology}

Blockchain is a pilot project that has become breakthrough and innovative around the world to ensure full business transparency of the largest state auction in Ukraine (over 4.5 billion UAH of assets sold). At the first stage of the introduction of Blockchain technology into the system of auctions, information is provided only on the rates, their sequence and size. At the second stage, the application is fixed and all the information that can be contained in the system is entered. It is possible to check the information provided about yourself and view information about other auction participants (Today, 2017).

World trends in 2017 indicate the active use of Blockchain technology. So, the energy company Eneres, with the support of Japanese authorities, is testing the capabilities of Blockchain technology with the purpose of building digital economy of joint use in the field of energy. Developers argue that due to Blockchain technology, business households, who use the energy generated by the solar panels, will be able to share surpluses of this energy with other members of the network for a certain reward (Gromyko, 2012; Blockchain technology..., 2017).

About 1 thousand households from Fukushima, Aizuwakamatsu and other cities of Fukushima Prefecture take part in the test project. Developers pose high hopes for this business project, which they say can "create an entirely new system of energy supply". Within the framework of the business project, Eneres will work with the developer of the software based on the Aizuwakamatsu and provide record of transaction data made on the Blockchain network. No virtual currency will be involved in testing, but if the test is successful, then it will demonstrate that households can buy and sell electricity using virtual currencies. In theory, 
Blockchain technology will integrate all households involved in this process into a "virtual power plant" (Japan will use Blockchain..., 2017).

In addition, the cryptographic products, such as bitcoin, based on the Blockchain technology, are introducing into the car market and car sharing. According to Reuters, EY, an Ernst \& Young Global consulting firm, on August 30, 2017 announced the launch of a special Blockchain system that would make car sharing more efficient and easy for companies and/or individuals. EY noted that the system, called Tesseract, would be launched together with the partner company by the end of 2017. Using Tesseract, users can record ownership of a car, schedule of use of the vehicle, and calculate insurance quotes, etc. EY is not the only company that intends to introduce Blockchain technology to the automotive market. Toyota Research Institute along with the Massachusetts Institute of Technology, is working on a number of common Blockchain projects. Moreover, Toyota is exploring the use of Blockchain in the area of "smart insurance" (Blockchain technology..., 2017).

In Zug (Switzerland), known for the highly developed ecosystem of crypto exchange startup, launching digital services of identity based on Ethereum. Government officials said that starting September 2017, they would offer a digital service of identification through a new application that unifies the identity and crypto address of user. Local residents will be able to register and pass a check by the city authorities. In terms of technology support, the application will run on the basis of the uPort identity platform, which was created by ConsenSys, the startup Ti\&m and Lucerne University of Economics (Digital passport..., 2017).

Authoritative jury of the first specialized competition of financial startups Fintech Master selected among 9 finalists a module for expressly evaluating the financial stability of the counterparty FinScore from YouControl. Fintech Master Open Data Incubator is the first specialized competition in Ukraine. The purpose of the competition is to develop new startups based on data from the National Bank and Mastercard, which were the general partners of the competition. It should be noted that YouControl is an analytical system that generates dossiers from each of Ukraine's companies based on open data from more than 40 sources, monitors changes in state registries, and visualizes relationships between affiliates. The unique technology of YouControl allows you to get the actual information (on request time) about a company or a FOP (individual entrepreneur) for a moment. The monitoring function reports daily changes in accordance with data from official sources.

The main business task of FinScore is a quick analysis of the financial strength of the counterparty, which helps to decide quickly on how to work with the counterparty taking into account financial risks. Thus, FinScore determines financial stability and probability of bankruptcy of the company. The uniqueness of the method lies in the fact that FinScore was created specifically for the analysis of companies in the Ukrainian market. From now on, any company in Ukraine, using YouControl, has access to a more convenient financial analysis. And for the independent adoption of such a business decision requires a staff of financial analysts within the company.

The key competence and, possibly, the resources owned by existing banks are the structure supported by the strictest provisions of financial regulation (Lerner \& Tufano, 2011). Accreditation will always be a challenging business-task for financial technologies and competing banks. However, it is in this context that cooperation between technology innovators and existing banks can help to improve the financial business services delivery system.

\section{Finance Hackathon}

An indication of the fact that our country "keeps up to date" is the presence of interesting and beyond doubt the perspective innovative business projects and the latest forms of their financing. Therefore, the Ukrainian startup Corezoid is a developer of a service that allows you to share access to a bank card, ranked second in the Money 20/20 Hackathon in Las Vegas. This startup became only representative of Europe in the world's largest financial hackathon (Basilenko, 2016).

We consider it necessary to point out that fintech is a sector of companies, that are using advanced technologies to improve financial business services, and hackathon is virtual meeting events, during which a large number of specialists innovators in the field of software development of financial sector intensively and cohesively working on solving the actual problem or creating a new application or service.

More than 600 developers from 106 teams took part in the competition. During the 24-hour work the teams presented their vision of the future of payment instruments and the financial market. Team Corezoid wins the nomination Visa Challenge and one of the prize places of Global Finance Hackathon has brought Share. CreditCard service, which allows users to share access to their bank card with each other. With the mobile app, Share.CreditCard users can easily share access to money, so friends and relatives will get a quick temporary access to a payment card to pay for a purchase in non-contact POS terminals or withdraw cash in ATMs with NFC support.

The Corezoid system is an open-source modular design with cloud-based data storage, which is based on the theory of finite automata using programming methods. Corezoid implements the concept of PostIT, in which software is not created from scratch, but is going to be a designer that can accelerate the launch of new products, reduce costs of supporting the existing IT infrastructure, and strengthen control of business processes within companies. 


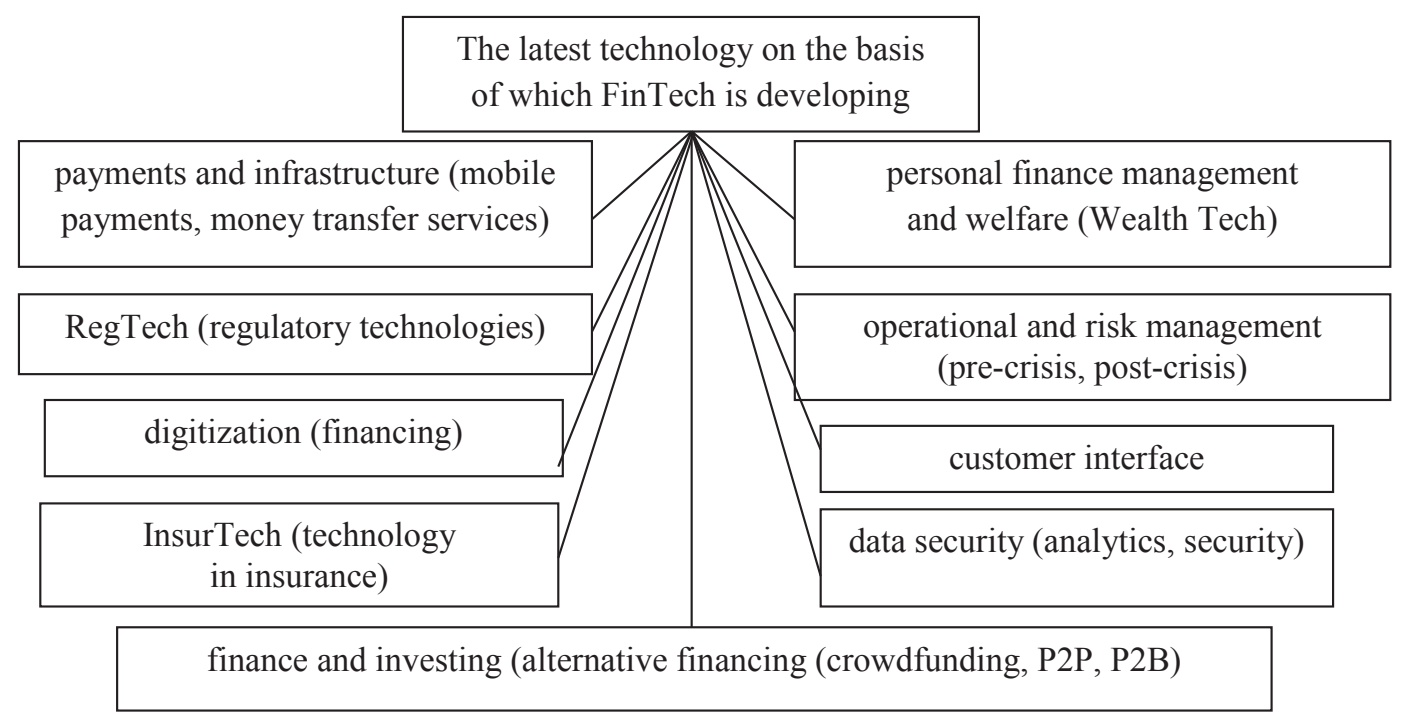

Figure 1. The latest technology based on FinTech's business trends

Source: development of authors

\section{FinTech's business trends}

Latest technology on basis of which a number of directions of FinTech in business are developing is presented in Figure 1.

The Ukrainian startups in the business process of implementing their successful projects are using the latest forms of their financing, namely, the crowdfunding platforms. It should be noted that crowdfunding means that investor should be given part of the company, and sponsors are only rewarded with public funding. Crowdfunding is considered one of the leading instruments of financing and supporting innovative business, especially in the consumer market, in postindustrial countries.

There are also micro-businesses, for which the crowdfunding platform for fundraising acts as advertising platform and a sales channel for financial products or hand-goods products (Crowdfunding, 2018).

An alternative to crowdfunding is crowdinvesting, or joint stock spread founding. It represents an alternative financial tool for attracting capital to startups and small business enterprises from a wide range of microinvestors. In 2013, the crowdinvesting market was estimated at
\$ 400 million, of which the USA accounted for about $50 \%$ (Crowdinvesting, 2018).

\section{Interconnection in the latest financial institution}

Of course, if there is a collective financing of an innovation business project, then there is a right to collective use of resources, which is crowdsourcing, which is transfer of certain production functions to an uncertain circle of persons (on the basis of a public offer, without an employment contract).

In general, crowd-technologies (crowdsourcing, crowdfunding) are an interesting and effective tool for solving business problems (Crowdsourcing, 2018). Ukraine has all the opportunities to apply crowdtechnologies in financial, economic, innovation, marketing, sales activities of enterprises. Interconnection in the latest financial institution of creative initiatives is presented in Figure 2.

Types of raising funds for the implementation of startup business projects and the peculiarities of management of innovative entrepreneurship through the crowdfunding platforms are given in Table 1 and Table 2.

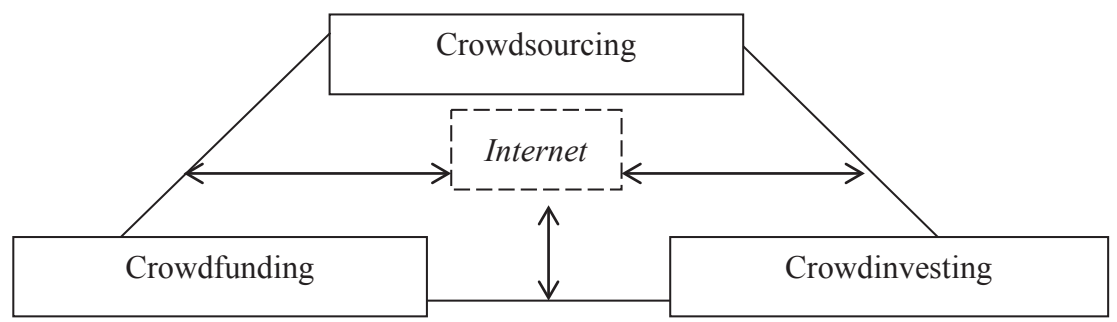

Figure 2. Interconnection in the latest financial institution of the implementation of creative initiatives

Source: development of authors 
Table 1

\section{Types of attraction funds and their examples}

\begin{tabular}{|l|l|l|l|}
\hline $\begin{array}{l}\text { Types of raising } \\
\text { funds through } \\
\text { crowdfunding }\end{array}$ & Features of raising funds in the form of a species & FinTech compa-nies & \multicolumn{1}{|c|}{ Amount of funding } \\
\hline 1 & 2 & 3 & 4 \\
\hline $\begin{array}{l}\text { Gratuitous or } \\
\text { charitable }\end{array}$ & Raising money for non-profit projects, no reward & Kickstarter, the USA, 2009 & $\begin{array}{l}146847 \text { projects were successfully } \\
\text { funded for a total of } \$ 3,800 \text { million }\end{array}$ \\
\hline Crowdinvesting & $\begin{array}{l}\text { Investments in the company are attracted in } \\
\text { exchange for its shares, and the funds raised are } \\
\text { directed towards development of the enterprise }\end{array}$ & Circle Up, the USA, 2012 & $\begin{array}{l}225 \text { start-ups were assembled with } \\
\text { a platform of } \$ 390 \text { million }\end{array}$ \\
\hline Factoring & $\begin{array}{l}\text { Investors buy unregulated busi-ness discount } \\
\text { invoices, and the seller uses unpaid bills as a } \\
\text { pledge to quickly get funding }\end{array}$ & Seedrs, the UK, 2012 & $\begin{array}{l}\text { Successfully funded } 650 \text { projects } \\
\text { totaling } £ 392 \text { million }\end{array}$ \\
\hline Debtor & $\begin{array}{l}\text { Funds are collected to finance individuals- } \\
\text { consumers and busi-ness on the basis of the loan, } \\
\text { with interest rates usually lower, and the investor } \\
\text { can choose the degree of permissible risk }\end{array}$ & Crowdcube, the UK, 2011 & $\begin{array}{l}\text { Successfully funded projects totaling } \\
£ 335 \text { million pounds at the end of Q1 } \\
2018\end{array}$ \\
\hline With reward & $\begin{array}{l}\text { Involves obtaining non-financial benefits in the } \\
\text { form of goods, works and works of art when } \\
\text { collecting funds for creative, cultural, sports } \\
\text { projects usually on the principle of "all } \\
\text { or nothing" }\end{array}$ & Indiegogo, the USA, 2011 & $\begin{array}{l}\text { More than 650 thou-sand projects } \\
\text { re-ceived funding for a total amount of } \\
\text { more than \$ 1 billion }\end{array}$ \\
\hline
\end{tabular}

Source: compiled by authors on the basis of (Angel, 2018; Arner, Barberis \& Ross, 2015; Holovatyuk, 2012)

Table 2

Types of attraction funds and peculiarities of management of innovative business through crowdfunding platforms

\begin{tabular}{|c|c|c|}
\hline $\begin{array}{l}\text { Types of raising } \\
\text { funds through } \\
\text { crowdfunding }\end{array}$ & Features of fundraising and its man-agement & Specialization \\
\hline 1 & 2 & 3 \\
\hline $\begin{array}{l}\text { Gratuitous } \\
\text { or charitable }\end{array}$ & $\begin{array}{l}\text { Project financing does not involve mon-etary compensation, but } \\
\text { it gives project sponsors the opportunity to use the ser-vice or to } \\
\text { obtain the goods created as a result of project implementation }\end{array}$ & $\begin{array}{l}\text { Funds are provided by individual investors } \\
\text { to projects that fall into one of the following } \\
\text { categories: art, crafts, design, food, fashion, } \\
\text { cine-ma, journalism, comics, games, music, } \\
\text { photography, theatre jour-nalism, technology }\end{array}$ \\
\hline Crowdinvesting & $\begin{array}{l}\text { Financing terms: the format of receiving funds "all or nothing"; } \\
\text { the investor's participation in the project involves receiving } \\
\text { a corresponding share of pre-ferred shares (less commonly- } \\
\text { ordinary shares or convertible bonds) in a funded company; the } \\
\text { company applying for financing pays a fee for the listing pro-cedure }\end{array}$ & $\begin{array}{l}\text { Financing of newly created and growing } \\
\text { companies in the field of consumer goods and } \\
\text { retail }\end{array}$ \\
\hline Factoring & $\begin{array}{l}\text { Project sponsors receive a stake in the company or convert it into a } \\
\text { discount for future investments; the minimum investment amount } \\
\text { is } £ 10 \text {; Payment processing fee }-0,5 \% \text {, and for adminis-trative } \\
\text { costs of the platform }-£ 2500\end{array}$ & $\begin{array}{l}\text { Financing of start-ups and growing companies of } \\
\text { various fields at the expense of investors from } 94 \\
\text { coun-tries of the world }\end{array}$ \\
\hline Debtor & $\begin{array}{l}\text { Minimum investment amount is } £ 10 \text {; investor's participation } \\
\text { involves one of two models, namely, corporatization (acquisition of } \\
\text { a stake in a company) and a fixed income model (purchase of fixed } \\
\text { rate bonds) }\end{array}$ & $\begin{array}{l}\text { Financing start-ups, newly created and growing } \\
\text { companies in various fields of business }\end{array}$ \\
\hline With reward & $\begin{array}{l}\text { Maximum collection time is } 60 \text { days; platform commission - } \\
5 \% \text { (for charity projects - } 0 \% \text { ); payment processing fee - } 3 \%+ \\
\$ 0,03 \text { per each contribution; the format of receiving funds is } \\
\text { chosen between "everything or nothing" and getting as much as it } \\
\text { was able to collect }\end{array}$ & $\begin{array}{l}\text { IT, media and entertainment, soft-ware, green } \\
\text { technologies, mobile communication, social } \\
\text { sphere, games }\end{array}$ \\
\hline
\end{tabular}

Source: compiled by authors on the basis of (Angel, 2018; Lerner \& Tufano, 2011; The pulse of fintech Q3 2017) 
It is worth noting that crowdfunding and crowdsourcing involve the attraction of financial resources through the Internet. Institutions that are presented in Figure 1 are influence of incentives, formal and informal financial rules and principles of conduct of all participants in the financial space, imposing restrictions on them while formulating a financial order, but the institutional "limits" of financial players on fintech hackathons are rather "blurred" and virtualized (Goloborodko, 2018).

Another mechanism for supporting startups may be creation of a so-called fund of funds. The purpose of creating such a fund and participation of the state is to support the IT industry itself. Something similar is realized in the field of film industry in Ukraine. State allocates funds to the Ukrainian State Film Agency, which in turn participates in the co-financing of Ukrainian films along with private companies. Fund of funds is an investment in professional funds, which in turn invests in other start-ups. The government is a coinvestor to help raise the necessary funds.

\section{Conclusions}

Today, we are witnessing the emergence of new digital business reality with quality financial institutions inherent in it and effective management of them. Technologies such as Blockchain, crowdfunding platforms, fintech are the leading qualitative financial instruments without which an innovative future is difficult to imagine. Institutions of this kind form an innovative financial ecosystem, underpinning the digital future of the economy.

New financial institutions may be similar to existing/ traditional institutions, as they are grown on their basis, and they also contain elements inherited from past ones that were already in operation. The higher quality of new financial institutions, the deeper the economy is digitized and the higher level of financial management.
New quality institutions that provide economic entities with appropriate incentives for financial activities can be considered effective, determine their desired behavior in terms of following the specific directions of innovation and digital transformation. It is necessary to form the newest financial institutions on the new socio-economic basis, having created a new institutional mechanism that ensures the effectiveness of social reproduction management symmetry in accordance with the new tasks set by the Government of Ukraine.

New financial institutions allow to improve quality of management through decentralized storage and protection of information and change the usual business functions of banks for us, provide complete transparency of business processes and save the free time of business entities that use digital financial institutions in their activities, new quality of administrative interaction between state institutions, society and enterprises. A financial institution such as crowdfunding is today deservedly considered one of the highest quality tools for financing and effectively supporting innovative business processes. This is due to the fact that crowdfunding platforms act both as an advertising platform and as a marketing channel for financial products/services.

As a result, it should be noted that the peculiarity of modern innovation-digital economic business development is the fact that the latest technologies, scientific potential of the sphere of innovation are the basic determinants that determine the formation of all possible foreign direct investment flows. Ukraine has significant scientific potential and it would be advisable to involve it more actively in the formation of investment flows into the national economy. The described experience of developed countries of the world shows that further research should be carried out in the direction of developing a concept of digital economy in the Ukrainian realities.

\section{References:}

Angel, L. (2018). Investing on Angel List. Retrieved from: https://angel.co/invest/start (accessed 15 November 2019).

Arner, D., Barberis, J., \& Ross, P. (2015). The evolution of fintech: a new post-crisis paradigm? University of hong kong faculty of law research Paper, 47, 1272-1319.

Basilenko, A. (2016). Ukrainskyi startap Corezoid vziav 2-he mistse na fintekh khakatoni Visa u Las-Vehasi [Ukrainian start-up Corezoid took 2nd place on Finteh Hakaton Visa in Las Vegas] (electronic journal). Retrieved from: http://watcher.com.ua/2016/10/24/ukrayinskyy-startap-corezoid-vzyav-2-he-mistse-na-finteh-hakatonivisa-u-las-vehasi/ (accessed 10 November 2019). (in Ukrainian)

Cassar, C., Heath, D., \& Micallef, L. (2018). What is digital economy? Unicorns, transformation and the Internet of things. Deloitte Article. Retrieved from: https://www2.deloitte.com/mt/en/pages/technology/articles/mt-whatis-digital-economy.html (accessed 12 November 2019).

Christensen, C., Raynor, M., \& McDonald, R. (2015). What is disruptive innovation? Harvard Business, 12, 44-53. Crowdfunding (2018). Wikipedia. Retrieved from: https://uk.wikipedia.org/wiki/Crowdfunding (accessed 15 November 2019).

Crowdinvesting (2018). Wikipedia. Retrieved from: https://ru.wikipedia.org/wiki/Crowdinvesting (accessed 15 November 2019). 
Crowdsourcing (2018). Wikipedia. Retrieved from: https://uk.wikipedia.org/wiki/Crowdsourcing (accessed 15 November 2019).

Goloborodko, O. (2018). Tsyfrova ekonomika: trendy ta perspektyvy avanhardnoho kharakteru rozvytku [Digital economy: trends and prospects for the avant-garde character of the development]. Effective economy, no. 1, (electronic journal). Retrieved from: http://www.economy.nayka.com.ua/pdf/1_2018/8.pdf (accessed 5 November 2019). (in Ukrainian)

Gromyko, V. (2012). Novaya ekonomika, kreativnaya ekonomika i prochie ponyatiynye innovatsii v ekonomicheskoy teorii [New economy, creative economy and other conceptual innovations in economic theory]. Bulletin of Plekhanov Russian Economic University, 3, 28-36. (in Russian)

Handbook of Payspace Magazine (2017). Tekhnologiya blokcheyn vykhodit na rynok avtomobiley i kar-shcheringa [Blokcheyn technology enters the automotive and car-sharing market]. Retrieved from: https://psm7.com/ news/texnologiya-blokchejn-vyxodit-na-rynok-avtomobilej-i-kar-sheringa.html (accessed 13 November 2019). (in Russian)

Handbook of Payspace Magazine (2017). Tsifroviy passport na blokcheyn:v Shchveytsarii sozdayut novyy servis [Digital passport on the Blokcheyn: in Switzerland will create a new service]. Retrieved from: https://psm7.com/ news/cifrovoj-pasport-na-blokchejne-v-shvejcarii-sozdadut-novyj-servis.html (accessed 10 November 2019). (in Russian)

Handbook of Payspace Magazine (2017). Yaponiya budit ispolzovat blokcheyn v sfere vozobnovlyaemoy energetiki [Japan will use Blokcheyn in renewable energy]. Retrieved from: https://psm7.com/news/yaponiya-budetispolzovat-blokchejn-v-sfere-vozobnovlyaemoj-energetiki.html (accessed 7 November 2019). (in Russian)

Handbook of Payspace Magazine (2017). Krupneyshchiy bank Izrailya i Microsoft testiruyut Blockchain [The largest bank of Israel and Microsoft is testing Blockchain]. Retrieved from: https://psm7.com/news/ krupnejshij-bank-izrailya-i-microsoft-testiruyut-blockchain.html (accessed 15 November 2019). (in Russian)

Holovatyuk, V. (2012). Investytsiina pryvabluvist innovatsiina sfery u konteksti ukrainskoi ekonomiky [Investment attractiveness of innovation sphere in the context of Ukrainian economy]. Science and science of science, 3, 110-127. (in Ukrainian)

Hroisman, V. (2017). Tsyfrova ekonomika sdatna strimko pidvyshyty VVP [Digital economy can rapidly increase GDP]. Retrieved from: http://ua-ekonomist.com/16214-cifrova-ekonomka-zdatna-strmko-pdvischiti-vvpgroysman.html (accessed 14 November 2019). (in Ukrainian)

Imperative (2017). Retrieved from: http://dic.academic.ru/dic.nsf/enc_philosophy/2339/ (accessed 14 November 2019). (in Ukrainian)

Lerner, J., \& Tufano, P. (2011). The consequences of financial innovation: a counterfactual research agenda. Annual Review of Financial Economics, 3,6 .

Palchuk, O. (2013). Innovatsiina ekonomika iak osnova rozvytku suchasnoho suspilstva [Innovative economy as a basis for the development of modern society]. Bulletin of the Kiev National University of Technology and Design, 1, 247-252. (in Ukrainian)

The pulse of fintech Q3 2017 (2017). Global analysis of investment in fintech. Retrieved from: https://assets.kpmg.com/ content $/ \mathrm{dam} / \mathrm{kpmg} / \mathrm{xx} / \mathrm{pdf} / 2017 / 11 /$ pulse-of-fintech-q3-17.pdf (accessed 12 November 2019). (in Ukrainian) Today (2017). Ukraina pervoi v mire provela blokchein-auktsion [Ukraine was the first in the world held Blockchain auction]. Retrieved from: http://www.segodnya.ua/economics/finance/ukraina-stala-pervoy-v-mire-provelablokcheyn-aukcion-1053662.html (accessed 9 November 2019). (in Russian)

Zatonatskaya, T. (2011). Problemy i perspektyvy innovatsiinogo rozvytky Ukrainy [Problems and prospects for snnovative development of Ukraine]. Scientific and Technical Information, 4, 19-24. (in Ukrainian)

Zavhorodnia, O. (2015). Funktsii innovatsii ta makroekonomichni eksternalii innovatsiinoi dynamiky [Functions of innovations and macroeconomic externalities of innovation dynamics]. Economic Herald, 3, 31-42. (in Ukrainian) Zhavoronkova, H., \& Zhavoronkova, V. (2015). Paradyhmalne modeliuvannia instytutsionalnykh zmin v informatsiinii ekonomitsi [Paradigmal modeling of the institutional changes in information economy]. Paradigm shifts in the economic theory of the XXI century: Materials of the 2nd International Scientific and Practical Conference, 2, 153-156. (in Ukrainian) 